\title{
The Effect of Perceived Quality, Brand Image, and Price Perception on Purchase Decision
}

\author{
Misbahul Anwar ${ }^{1 *}$, Dodi Andrean ${ }^{1}$ \\ ${ }^{1}$ Universitas Muhammadiyah Yogyakarta, Indonesia \\ ${ }^{*}$ Corresponding author.Email: misbahulanwar@umy.ac.id
}

\begin{abstract}
This study aims to determine the influence of perceived quality, brand image, and price perception on the decision to purchase airline tickets online at traveloka.com customers. The number of samples used in this research was 200 respondents, who were users of the traveloka.com website to purchase plane tickets online in the Special Region of Yogyakarta. Purposive sampling was employed as a sampling technique. Meanwhile, multiple regression analysis was utilized as a method of analysis to determine the influence of the variables involved. This study's results indicated that simultaneously, perceived quality, brand image, and price perception positively and significantly influenced purchase decisions. Partially, perceived quality positively and significantly affected purchase decisions. Partially, brand image positively and significantly impacted purchase decisions. Moreover, partially, price perception had a positive and significant effect on purchase decisions.
\end{abstract}

\section{Keywords: Perceived Quality, Brand Image, Price Perception, Purchase Decision}

\section{INTRODUCTION}

The rapid enhancement of the internet has enabled consumers to find information and buy products through the internet. The internet offers consumers opportunities to use online purchasing facilities effectively and efficiently by increasing the availability of information on products and services [14]. Information technology development has led to many emerging startups that offer online ordering and purchasing services [7]. Several startups provide services in selling tickets online.

Meanwhile, purchasing decisions are critical for companies to consider in maintaining and developing their business [13]. Regarding product quality, according to Deavaj, it is crucial to be considered as a factor influencing purchasing decisions. The products offered by the company must have values in accordance with what is expected by the customer [8].

A large number of brands provide choices to consumers in purchasing. The intense market competition encourages consumers to consider the brand image of the products offered [15]. There is a tendency for consumers to choose products that have been recognized through the experience of using the product or based on information obtained through various sources. Rahmi and Nizam [11] explained that a positive brand image makes consumers like brands sustainably. For the companies, the right brand images will strengthen their brand in competing with other brands.

According to [2], one of the purchasing decisions' influences is the customer's perceptions of prices. Price perception is the tendency of consumers to use prices in assessing product quality [2].

Therefore, this study aims to show the empirical impact of perceived quality, brand image, and price perception on purchasing decisions at online ticket provider traveloka.com.

\section{THE DEVELOPMENT OF HYPOTHESES}

\section{The Influence of Perceived Quality, Brand Image, and Price Perception on Purchasing Decisions}

Research by [2] revealed that product quality, brand image, and price perception positively affected purchasing decisions. [9] also explained that product quality, brand image, and price perception significantly influenced purchasing decisions. Besides, Amron's research [1] found that brand image, brand trust, product quality, and price positively impacted consumers' purchasing decisions. Based on the results of these 
explanations, the following research hypothesis was proposed:

H1: Perceived quality, brand image, and price perception have a positive effect on purchasing decisions.

\section{The Effect of Perceived Quality on Purchasing Decisions}

Kotler and Kellerelucidated that "the heart of the marketing program is the product." To create a competitive advantage, companies must create products or services following the values expected by consumers [6]. A study conducted by Amron [1] discovered that perceived quality had a positive effect on purchasing decisions. Research by Muharam and Soliha [9[ uncovered that perceived quality influenced purchasing decisions. Fatmawati and Soliha (2017), in their research, also found that perceived quality had a positive impact on purchasing decisions.

Based on these findings, the hypothesis was proposed:

$\mathrm{H} 2$ : The perceived quality has a positive effect on purchasing decisions.

\section{The Effect of Brand Image on Purchasing Decisions}

Foster's [3] research clarified that brand image positively affected purchasing decisions. Fatmawati and Soliha [2], in their research, uncovered that brand image had a positive effect on consumer's purchasing decisions. Amron [1] also found that brand image positively impacted purchasing decisions. is:

Based on the above findings, the research hypothesis

H3: Brand image has a positive effect on purchasing decisions.

\section{The Effect of Price Perception on Purchasing Decisions}

Fatmawati and Soliha [2] research found that price perception had a positive effect on consumer purchasing decisions. Harwani and Pradita [5], in their research, revealed that price perception influenced purchasing decisions. Muharam and Soliha [9] also explained similar results that price perception positively affected purchasing decisions.

Based on these findings, the hypothesis was proposed:

H4: Price perception has a positive effect on purchasing decisions.

\section{RESEARCH SAMPLE}

This research used respondents of online ticketing service users Traveloka.com. The number of respondents was 200 who lived in Yogyakarta. Sampling employed a purposive sampling technique, with the respondent who had used traveloka.com services.

\section{Instrument and Measurement}

This study used primary data obtained from questionnaires filled out by respondents. The research variables included perceived quality, brand image, price perception, and purchasing decisions, measured by a 5Likert scale that illustrated from strongly disagree to agree strongly.

\section{THE DATA ANALYSIS RESULTS}

Hypothesis testing techniques utilized multiple regression with the SPSS program. The analysis was performed by testing the significance of the independent variables' influence simultaneously and partially in the research model. It was by measuring the significance of the regression coefficient. To test the questionnaire items' accuracy, the factor validity test was used, and questionnaire consistency testing employed Cronbach's Alpha [4].

The results of testing the validity and reliability of the questionnaire items are presented in the following table:

Table 1: Testing Questionnaire Items

\begin{tabular}{|c|c|c|c|}
\hline \multicolumn{2}{|c|}{ Variables and Indicators } & Sig. & $\begin{array}{l}\text { Cronbach } \\
\text { Alpha }\end{array}$ \\
\hline \multicolumn{2}{|c|}{ Perceived Quality } & & 0,694 \\
\hline 1 & $\begin{array}{l}\text { Traveloka sites and applications are } \\
\text { easy to learn to operate. }\end{array}$ & 0,000 & \\
\hline 2 & $\begin{array}{l}\text { Interaction with Traveloka sites is easy } \\
\text { to understand. }\end{array}$ & 0,000 & \\
\hline 3 & Traveloka's site is easy to navigate. & 0,000 & \\
\hline 4 & The Traveloka site is easy to use. & 0,033 & \\
\hline 5 & The Traveloka site looks interesting. & 0,001 & \\
\hline 6 & $\begin{array}{l}\text { Traveloka provides accurate } \\
\text { information. }\end{array}$ & 0,002 & \\
\hline 7 & $\begin{array}{l}\text { Traveloka provides reliable } \\
\text { information. }\end{array}$ & 0,001 & \\
\hline 8 & $\begin{array}{l}\text { Traveloka provides timely } \\
\text { information. }\end{array}$ & 0,003 & \\
\hline 9 & $\begin{array}{l}\text { Traveloka provides relevant } \\
\text { information. }\end{array}$ & 0,001 & \\
\hline 10 & $\begin{array}{l}\text { Traveloka provides information that is } \\
\text { easy to understand. }\end{array}$ & 0,000 & \\
\hline 11 & $\begin{array}{l}\text { Traveloka can complete transactions } \\
\text { safely. }\end{array}$ & 0,037 & \\
\hline
\end{tabular}




\begin{tabular}{|c|c|c|c|}
\hline 12 & $\begin{array}{l}\text { Traveloka stores personal information } \\
\text { safely. }\end{array}$ & 0,041 & \\
\hline 13 & $\begin{array}{l}\text { The Traveloka site presents } \\
\text { convenience in communication. }\end{array}$ & 0,009 & \\
\hline 14 & $\begin{array}{l}\text { The services provided by Traveloka } \\
\text { are as promised. }\end{array}$ & 0,014 & \\
\hline \multicolumn{2}{|c|}{ Brand Image } & & 0,646 \\
\hline 1 & $\begin{array}{l}\text { Traveloka is a popular online airline } \\
\text { ticket purchase site. }\end{array}$ & 0,001 & \\
\hline 2 & $\begin{array}{l}\text { Traveloka has a good reputation as an } \\
\text { online airline ticket purchase site. }\end{array}$ & 0,008 & \\
\hline 3 & $\begin{array}{l}\text { Traveloka's online flight ticket } \\
\text { purchase site is widely known. }\end{array}$ & 0,003 & \\
\hline 4 & $\begin{array}{l}\text { Traveloka is a popular online airline } \\
\text { ticket purchase site. }\end{array}$ & 0,000 & \\
\hline 5 & $\begin{array}{l}\text { Traveloka has a good reputation as an } \\
\text { online airline ticket purchase site. }\end{array}$ & 0,000 & \\
\hline 6 & $\begin{array}{l}\text { Proud to use Traveloka as an online } \\
\text { flight ticket purchase service }\end{array}$ & 0,050 & \\
\hline 7 & $\begin{array}{l}\text { Traveloka gives a classy impression } \\
\text { when using it. }\end{array}$ & 0,050 & \\
\hline \multicolumn{2}{|c|}{ Price Perception } & & 0,630 \\
\hline 1 & $\begin{array}{l}\text { Traveloka presents prices according to } \\
\text { the quality offered. }\end{array}$ & 0,000 & \\
\hline 2 & $\begin{array}{l}\text { Traveloka presents prices that } \\
\text { match the perceived benefits. }\end{array}$ & $02^{0,0}$ & \\
\hline 3 & Traveloka offers affordable prices. & $00^{0,0}$ & \\
\hline \multicolumn{2}{|c|}{ Purchase Decision } & & 0,648 \\
\hline 1 & $\begin{array}{l}\text { Buying airline tickets online in } \\
\text { Traveloka suits my needs. }\end{array}$ & 0,000 & \\
\hline 2 & $\begin{array}{l}\text { There is confidence in buying plane } \\
\text { tickets online at Traveloka. }\end{array}$ & 0,033 & \\
\hline 3 & $\begin{array}{l}\text { Buy plane tickets online in Traveloka at } \\
\text { a future time }\end{array}$ & 0,006 & \\
\hline 4 & $\begin{array}{l}\text { Buying airline tickets online in } \\
\text { Traveloka for reliable }\end{array}$ & 0,001 & \\
\hline
\end{tabular}

\section{RESULTS}

The goodness of fit model test results showed the value of $F$ 128.966. Thus, the research model built could be used to analyze the effect of perceived quality, brand image, and price perception on purchasing decision variables.

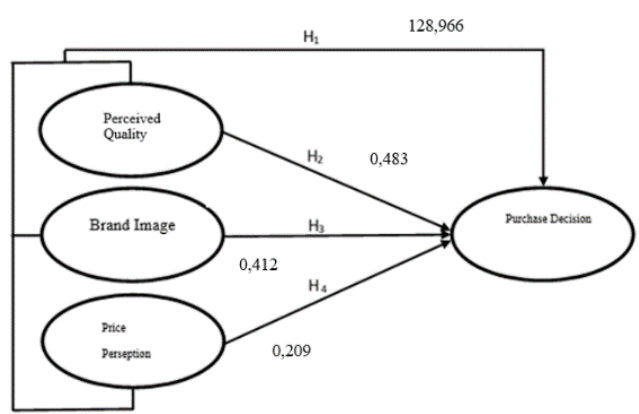

Figure 1: Effect of Perceived Quality, Brand Image, and Price Perception on Purchasing Decisions

Table 2 presents the regression coefficients of each independent variable and their effect on purchasing decisions.

Table 2: Hypothesis Testing

\begin{tabular}{|c|c|c|c|c|c|c|}
\hline $\begin{array}{l}\text { Hypothes } \\
\text { is }\end{array}$ & & $\begin{array}{l}\text { F } \\
\text { Value }\end{array}$ & $\begin{array}{l}. t \\
\text { Valu } \\
\text { e }\end{array}$ & $\begin{array}{l}\text { Coe } \\
\text { f. }\end{array}$ & Sig & Result \\
\hline H1 & $\begin{array}{l}\text { Perceived } \\
\text { Quality, } \\
\text { Brand } \\
\text { Image, } \\
\text { Price } \\
\text { Perception } \\
\rightarrow \\
\text { Purchasing } \\
\text { Decision }\end{array}$ & $\begin{array}{l}128,96 \\
6\end{array}$ & & & $\begin{array}{l}0,00 \\
0\end{array}$ & $\begin{array}{l}\text { Significa } \\
\text { nt }\end{array}$ \\
\hline H2 & $\begin{array}{l}\text { Perceived } \\
\text { Quality } \rightarrow \\
\text { Purchasing } \\
\text { Decision }\end{array}$ & & $\begin{array}{l}10,64 \\
7\end{array}$ & $\begin{array}{l}0,48 \\
3\end{array}$ & $\begin{array}{l}0,00 \\
0\end{array}$ & $\begin{array}{l}\text { Significa } \\
\text { nt }\end{array}$ \\
\hline H3 & $\begin{array}{l}\text { Brand } \\
\text { Image } \rightarrow \\
\text { Purchasing } \\
\text { Decision }\end{array}$ & & 9,155 & $\begin{array}{l}0,41 \\
2\end{array}$ & $\begin{array}{l}0,00 \\
0\end{array}$ & $\begin{array}{l}\text { Significa } \\
\text { nt }\end{array}$ \\
\hline H4 & $\begin{array}{l}\text { Price } \\
\text { Perception } \\
\rightarrow \\
\text { Purchasing } \\
\text { Decision }\end{array}$ & & 4,942 & $\begin{array}{l}0,20 \\
9\end{array}$ & $\begin{array}{l}0,00 \\
0\end{array}$ & $\begin{array}{l}\text { Significa } \\
\text { nt }\end{array}$ \\
\hline Not & ificant & 5. & 4, & $\geq 1$, & & \\
\hline
\end{tabular}

Table 2 displays the influence of perceived quality, brand image, and price perception on purchasing decisions. The calculated $F$ value and $t$ value indicated a positive and significant influence of each variable.

The influence of perceived quality, brand image, and price perception on purchasing decisions showed a positive and significant effect on the F-value $=128,966>$ 
4.63 , with a significance value of $0,000<0.05$. Therefore, hypothesis 1 was accepted.

The effect of perceived quality on purchasing decisions based on regression calculations revealed a positive and significant effect, seen from the $\mathrm{t}$-value $=$ $10.647>1.96$ and the significance value of $0.000<0.05$. Thus, hypothesis 2 was accepted.

The influence of brand image on purchasing decisions based on regression calculations indicated a positive and significant effect, seen from the t-value $=9,155>1.96$ and a significance value of $0,000<0.05$. Therefore, hypothesis 3 was accepted.

The effect of price perception on purchasing decisions based on regression calculations confirmed a positive and significant effect, seen from the $\mathrm{t}$-value $=$ $4.942>1.96$ and the significance value of $0,000<0.05$. Thus, hypothesis 4 was accepted.

\section{DISCUSSION}

This research provides information on the factors of perceived quality, brand image, and price perceptions' influence on purchasing decisions. This study's results are in line with research by Fatmawati and Soliha [2], Muharam and Soliha [9], and Amron [1], which explained that product quality, brand image, and price perception had a positive effect on purchasing decisions.

In this study, perceived quality gave the most dominant influence compared to other variables. The findings revealed that quality is an essential factor in determining a business's success. This study's results are in agreement with research by Muharam and Soliha [9], Fatmawati and Soliha [2], and Amron [1], exposing the positive effect of product quality on purchasing decisions.

Besides, the test results exposed that brand image positively and significantly influenced purchasing decisions. It indicated that the brand image had an impact on purchasing decisions. This study's results align with the findings of Muharam and Soliha [9], Foster [3], Fatmawati and Soliha [2], Harwani and Pradita [5], Yasmin [16], and Amron [1], which uncovered that brand image had a positive and significant impact on the purchase decision.

Furthermore, testing the effect of price perceptions on purchasing decisions showed a positive and significant influence of price perceptions on purchasing decisions. It signified that the better the consumer's perception of the price would further increase purchasing decisions. This test's results support research conducted by Muharam and Soliha [9], Nusarika and Purnami [10], Fatmawati and Soliha [2], and Harwani and Pradita [5], which stated that price perceptions significantly affected purchasing decisions.

\section{THEORETICAL CONTRIBUTION AND CONCLUSIONS}

This study provides empirical facts that perceived quality, brand image, and price perception significantly influenced consumers' purchasing decisions, which is in line with previous research. It informs companies of the importance of presenting good quality, building a strong brand image, and carefully managing pricing policies to encourage consumers to make purchasing decisions. This research's theoretical contribution is to strengthen previous studies stating that perceived quality, brand image, and price perceptions are the main variables affecting purchasing decisions.

\section{REFERENCES}

[1] Amron, Amron. 2018. "The Influence of Brand Image, Brand Trust, Product Quality, and Price on the Consumer's Buying Decision of MPV Cars." European Scientific Journal, Vol.14, No.13, pp. 228-239.

[2] Fatmawati, Nurul, and Soliha, Euis. 2017. "Product Quality, Brand Image, and Price Perceptions of the Purchasing Decision Process of Honda Matic Motorcycles." Journal of Theory and Applied Management, Year 10, No. 1, pp.: 1-20.

[3] Foster, Bob. 2016. "Impact of Brand Image on Purchasing Decision on Mineral Water Product Amidis (Case Study on Bintang Trading Company)." American Research Journal of Humanities and Social Science, Vol. 2, pp. 1-11

[4] Ghozali, Imam. 2016. Multivariate Analysis Application with the IBM SPSS 23 Program 8th Edition. Semarang: Diponegoro University.

[5] Harwani, Yuli, and Pradita, Shindy Ramadiyani. 2017. "Effect of Brand Image and Perceived Price Towards Purchase Decision in Kentucky Fried Chicken (KFC)." Journal of Marketing and Consumer Research. Vol. 37, pp. 13-23.

[6] Kotler, Philip, and Keller, Kevin Lane. 2016. Marketing Management 15e Global Edition. England: Pearson.

[7] Kriechbaumer, Florian and Christodoulidou, Natasa, 2014, "SME website implementation factors in the hospitality industry Groundwork for a digital marketing roadmap," Worldwide Hospitality and Tourism Themes, Vol. 6, No. 4, pp. 328-351

[8] Mal, Lydya Herlina, and Mertayasa, I Gede Agus 2018. "The Effect of Price, Promotion, and Quality of Service on Purchasing Decisions on Airplane Tickets Online on Traveloka.com Site for Management Studies Students at the Faculty of 
Economics and Humanities at Dhyana Pura University in Bali" Journal of Dhyana Pura University. Vol. 13, No. 1, pp. 63-73.

[9] Muharam, Wifky, and Soliha, Euis. 2017. "Product Quality, Brand Image, Price Perception, and Purchasing Decisions of Honda Mobilio Consumers." Proceedings of the Multi-Disciplinary National Seminar \& Call For Papers UNISBANK, pp. $755-762$.

[10] Nusarika, Luh Alviolita Kusuma, and Purnami, Ni Made. 2015. "The Effect of Price Perception, Trust, and Shopping Orientation on Online Purchase Intention (Study on Online Fashion Products in Denpasar City)." Unud Management E-journal, Vol.4, No.8, pp. 2380-2406.

[11] Rahmi, Delsi Tuttia, and Nizam, Ahmad. 2017. "The Effect of Brand Image on Intention to Purchase Airplane Tickets Online on Traveloka.com Consumers with Trust as Mediation Variables" Scientific Journal of Management Economics Students, Vol. 2, No.3, pp. 70-85.

[12] Risyandi, Okki, and Zulestiana, Dinda Amanda. 2017. "Effect of Traveloka Website Quality on User Satisfaction" e-proceeding of management, Vol. 4, No. 3. pp. 2244-2251.

[13] Sanyal, Nath Shamindra and Datta, Saroj Kumar, 2011. "The effect of perceived quality on brand equity: an empirical study on generic drugs," Asia Pacific Journal of Marketing and Logistics, Vol. 7, No. 5, pp. 604-625

[14] Sharma, Amalesh, 2011, "Take-off of online marketing: casting the next generation strategies," Business Strategy Series, Vol. 12, No. 4, pp. 202208

[15] Snoj, Boris, Korda, Aleksandra Pisnik and Mumel, Damijan, 2004, "The relationships among perceived quality, perceived risk, and perceived product value," Journal of Product \& Brand Management, Vol. 13, No. 3, pp. 156-167

[16] Yasmin, Afriana. 2017. "Impact of Brand Image on Consumers Purchase Decision." International Journal of Research in Social Science, Vol. 7, Issue 10, pp. 627-644. 